\title{
HOW MAY WE SPEAK OF GOD? A RECONSIDERATION OF THE NATURE OF BIBLICAL THEOLOGY ${ }^{1}$
}

\author{
R.W.L. Moberly
}

\begin{abstract}
Summary
If theological interpretation of Scripture is to be renewed, it is necessary initially to acknowledge the strength of objections to theological interpretation in the 19th century when the modern paradigm of historical criticism was established; Pusey's messianic interpretation of Haggai 2:7 serves as a case study. Late 20th century work in hermeneutics changes the frame of reference within which the task should be conceived, though its potential has not yet been fully utilized by biblical scholars; Preuss's discussion of revelation in his Old Testament Theology serves as a case study. Finally, the divine self-revelation in Exodus 34:6-7 is seen to provide rules for, and constraints upon, truthful speech about God; and if the biblical text itself is to be understood as revelatory then the work of the interpreter needs ultimately to be understood as an act of prayer.
\end{abstract}

\section{Introduction}

Those of us who pursue biblical theology (by whatever name we call it) ${ }^{2}$ usually do so out of a conviction of the importance of the dis-

1 Tyndale Biblical Theology Lecture 2002. I am grateful to Jennifer Moberly, Stephen Barton and David Day for comments on a draft of this paper.

2 Both 'biblical' and 'theology' are used in differing ways that can create misunderstanding. 'Biblical' may simply designate 'anything found within the Bible', whereas here I am using it to depict 'relating to the Bible as a whole' (for which James Barr reserves the term 'pan-biblical' [The Concept of Biblical Theology: An Old Testament Perspective (London: SCM, 1999), 1]). 'Theology' may mean 'a historical study of religious concepts', as in TDOT, or it may signify 'an account of that which is believed by Christians (or Jews or Muslims) to be enduringly true about God and life'. I have some preference for 'theological interpretation of Scripture' over 'biblical theology'. The use of the religious category 'Scripture' rather than the more neutral 'Bible', together with the use of 'theological' as an 
cipline for the life and health of the Christian Church. For if Scripture is not only the primary source but also the fundamental norm of Christian faith (however much we may continue to debate what these do, and do not, entail), then the ability to clarify, communicate and appropriate what Scripture says about God and humanity is an enduring need, constantly to be renewed as the broader contexts of human life and thought develop and change. Biblical theology is thus, in some form or other, the endeavour to speak and/or write truthfully about God via the interpretation of Scripture where God's selfrevelation to Israel and in Christ is to be found.

Yet a good number of our colleagues in biblical studies not only do not envisage their own work in these terms, for they celebrate the plurality of purposes with which the biblical text may validly be approached, but they also express doubts as to the feasibility of the task even for those who would undertake it. As Brevard Childs' successor at Yale, John J. Collins, puts it:

Biblical theology is a subject in decline ... The cutting edges of contemporary biblical scholarship are in literary criticism on the one hand and sociological criticism on the other. Not only is theology no longer queen of the sciences in general, its place even among the biblical sciences is in doubt. $^{3}$

This uncheering prospect at least assumes that biblical theology is a recognizable discipline. But some scholars would question whether even that much can be affirmed. As Phyllis Trible puts it:

Biblical theologians, though coming from a circumscribed community, have never agreed on the definition, method, organization, subject matter, point of view, or purpose of their enterprise. ${ }^{4}$

That leaves out little! To be sure, such uncertainties usually do not inhibit scholars from going on to formulate their own positive

adjective to depict what the interpreter is doing, tends towards an understanding of the task in a more existential and engaged sense.

3 J.J. Collins, 'Is a Critical Biblical Theology Possible?' in W.H. Propp, B. Halpern \& D.N. Freedman (eds.), The Hebrew Bible and Its Interpreters (Winona Lake, IN: Eisenbrauns, 1990), 1-17 (1).

4 Phyllis Trible, 'Five Loaves and Two Fishes: Feminist Hermeneutics and Biblical Theology', in Theological Studies 50 (1989), 279-95 (281); repr. in J. Reumann (ed.), The Promise and Practice of Biblical Theology (Augsburg: Fortress: 1991), 51-70 (53), and in B.C. Ollenburger, E.A. Martens \& G.F. Hasel (eds.), The Flowering of Old Testament Theology (Winona Lake, IN: Eisenbrauns, 1992), 448-64 (451). Not dissimilar is Don Carson's comment: 'The history of "biblical theology" is extraordinarily diverse. Everyone does that which is right in his or her own eyes, and calls it biblical theology' ('Systematic theology and biblical theology' in T.D. Alexander \& B.S. Rosner [eds.], New Dictionary of Biblical Theology [Leicester: IVP: 2000], 89-104 [91]). 
proposals. It means, however, that all proposals about the nature and purpose of biblical theology require that special kind of persuasiveness which is necessitated on the part of the proponents of any project whose status and viability is in question.

For present purposes I do not wish to give any overview of contemporary debate, valuable though that might be (since on some readings of the situation matters are less gloomy than Collins, and less controverted than Trible, supposes). Rather I wish to offer one positive proposal, to do with the nature of God and of religious language within Scripture. I will approach this via some discussion of approaches to biblical theology which seem to me unsatisfactory (which I do not out of a desire to score cheap points at others' expense, but because a reasoned account of why unsatisfactory work is unsatisfactory can often be illuminating). For reasons of space I will restrict my discussion to the Old Testament, where the issues of appropriation for Christian faith tend to be hardest, even though the thesis could equally be argued with reference to the New Testament. 5

\section{Why Theological Interpretation Might Be a Bad Thing: The 19th Century Example of Pusey}

First, I wish to set the scene by a reminder of why many biblical scholars are more or less uneasy with renewed proposals for biblical theology.

A theological account of the nature of Scripture, together with the actual practice of theological interpretation, is often resisted by biblical exegetes on the grounds that it tends, in one way or other, to encourage what amounts to at best a narrowing, more likely a skewing, and at worst a manipulativeness, in the handling of the text: one may make historical affirmations that cannot be supported by the available evidence (perhaps either about the historicity of certain events, or about the distinctiveness of the biblical material in relation to its cultural context); one may move interpretation onto an abstract level that loses the intrinsic richness of the text; one may anachronistically make the text conform to a traditional interpretation when its sense in its own context is different; and so on. It can be

5 For an analysis of 'God is love' in $1 \mathrm{Jn}$. 4, which complements this paper's study of Ex. 34:6-7, see my "Test the Spirits": God, Love, and Critical Discernment in 1 John 4' forthcoming in G. Stanton, S. Barton, B. Longenecker (eds.), The Holy Spirit and Christian Origins (Grand Rapids: Eerdmans, 2003). 
salutary to return to some of the literature of the 19th century where the modern paradigm of biblical scholarship took shape. To read some of the 19th century defenders of theological interpretation, such as Pusey or Hengstenberg (especially, but not only, when they had a bad day), can give a renewed appreciation of why so many scholars came to feel that integrity required the expulsion of most ecclesial and confessional assumptions from the work of exegesis. ${ }^{6}$

I would like to consider an example from E.B. Pusey-not from his best known and most overtly polemical Lectures on Daniel the Prophet, ${ }^{7}$ but from his Minor Prophets where Pusey could be considered to be working in 'normal' mode: his exposition of the famous words in Haggai 2:7, ûba'û hemdat kol-haggôyîm ûmille't $t \hat{1}$ 'et-habbayit hazzeh kabôd. ${ }^{8}$ A typical modern translation is that of the NRSV: 'so that the treasure of all nations shall come, and I will fill this house with splendour', where the sense is that the valuables of many countries shall be brought in to adorn the renewed temple, in keeping with Haggai's contextual concern for the restoration of the temple; a construal whose correctness seems to me beyond doubt. Pusey retains the AV translation, 'the desire of all nations shall come, and I will fill this house with glory', and he interprets it messianically (as immortalized by Handel): 'The words can only mean this, the central longing of all nations; He whom they longed for, either through the knowledge of Him spread by the Jews in the Dispersion, or mutely by the aching craving of the human heart, longing for the restoration from its decay...' (Pusey often writes movingly). The primary justification is messianic construal by both

6 I say 'most assumptions' because some major assumptions were almost universally retained: the privileging significance of the concept of 'canon', such that canonical texts are generally (though with many exceptions) more significant than non-canonical texts (or at least qualifying for numerous commentaries that non-canonical texts have not, until recently, received); and the belief that the deity of (at least some of) the biblical text is not other than the deity in whom Jews and Christians still believe, as exemplified in the privileging convention of capitalizing 'God' as distinct from 'god' or 'gods' - a distinction not present within the texts themselves.

7 Oxford \& London: Parker \& Rivingtons, 1864. There are some fascinating and sympathetic reflections on Pusey's concerns in C. Seitz, 'Scripture Becomes Religion(s): The Theological Crisis of Serious Biblical Interpretation in the Twentieth Century' in C. Bartholomew, C. Greene, K. Möller (eds.), Renewing Biblical Interpretation (Carlisle \& Grand Rapids: Paternoster \& Zondervan, 2000), 40-65; repr. in his Figured Out: Typology and Providence in Christian Scripture (Louisville: Westminster/John Knox, 2001), 13-33.

8 The Minor Prophets, Vol. VII. Zephaniah and Haggai (London: Nisbet, 1907), 247-55. 
Jews and Christians in antiquity, within the context of the Pauline notion of the whole creation groaning in travail and longing to be set free. Pusey is aware of the construal in terms of treasures adorning the temple, and dismisses it in two ways. First, he gives a long note on Hebrew usage of $\sqrt{ } \mathrm{hmd}$, which concludes that 'the costly things of all peoples' would 'if expressed by the word at all' have been mahămaddê kol-haggoyîm. Secondly, with regard to 'glory', Pusey appeals to Solomon's temple and Ezekiel's ideal temple, where the glory clearly depicts God Himself, then asks rhetorically, 'When then of this second temple God uses the self-same words, that He will fill it with glory, with what other glory should He fill it than His own?', and he concludes with a flourish, 'To interpret that glory of anything material, is to do violence to language, to force on words of Scripture an unworthy sense, which they refuse to bear'.

There are, sadly, some obvious objections. First, Pusey does not accurately set out and address an obvious grammatical problem, that the singular hemdat has a plural verb $\hat{u}_{b} \bar{a}^{-} \hat{u}$. He does indeed refer to it in passing, in the course of the exposition, but does not see it as a problem in the light of Ps. 119:103 where 'a psalmist expresses at once the collective, 'God's word' and the 'words' contained in it, by an idiom like Haggai's, joining the feminine singular as a collective with the plural verb: How sweet are Thy word unto my taste (mh nmlsw lhky 'mrtk)'. Although the MT indeed points 'word' as a singular, Pusey fails to mention that it could be repointed as a plural without alteration of the consonantal text, and that this is how the LXX renders it (hôs glukea...ta logia sou). Nor does he establish on philological grounds that the MT pointing of the psalm would constitute an appropriate parallel to the anomalous usage in Haggai, beyond some general observations about 'the delicacy of the phrase, whereby manifoldness is combined in unity, the Object of desire containing in itself many objects of desire'. Secondly, Pusey's comment that 'costly things' would have to be mahămaddê is simply mistaken; as in Ps. 119:103 the singular hemdat could without alteration to the consonantal text be repointed as a plural passive participle, hămūdot, 'desired things', which is already the construal of the LXX, ta eklekta (Pusey makes no mention of the LXX). Thirdly, the possibility that Haggai might mean something different, and apparently less spiritual than earlier writers in their accounts of the glory of YHWH (i.e. that Haggai's concern might indeed be material splendour rather than the cloud of divine presence), is not allowed to receive proper discussion. Pusey's culminating thrust is to take the 
moral high ground, that to argue in terms of material splendour is to force on words of Scripture an unworthy sense, so that the suggestion is one to be ashamed of in face of its more worthy alternative. That Pusey himself might be forcing the text, and prejudging instead of discussing what the significance of the proposed alternative might be, is by implication also an improper thought.

When, therefore, a senior scholar shows himself incapable of properly setting out and fairly discussing a fairly straightforward issue of Hebrew text and language and the evidence of the versions; when ancient and medieval scholars are consistently preferred to moderns as though there were nothing new to be learned in terms of philology and history; when attention to the Hebrew text in its literary context is recurrently displaced by theological axioms and homiletical application;9 and when moral and spiritual superiority is claimed for an approach to the text that is at best blinkered and at worst dishonest - then it is not difficult to see why a disciplined philological and historical approach to the text which excluded traditional and ecclesial theology came to be seen as the only way to ensure proper scholarship in a biblical context. Such historical scholarship, moreover, far from emptying the Bible of its theological significance, would rather, precisely by virtue of its attentiveness to the true meaning of the biblical text, be religiously far more fruitful than any alternative.

It is with mixed feelings that I set Pusey up as a model of bad scholarship, for I think that Pusey's deepest instincts were in many ways sound. He rightly sensed that the increasingly rationalistic mood of biblical scholarship could pose serious problems for the church's historic understanding of the relationship between reason and faith and its mode of construing Scripture in relation to the truth of God. But he neither rightly grasped the nature and purpose of contemporary German biblical criticism, nor did he know how to articulate the

9 By contrast, Calvin's exposition of the problem is a model. He sets out the two possibilities, treasures of the nations and reference to Christ, and decides for the former on contextual grounds (Commentaries on the Twelve Minor Prophets: Vol. 4: Habakkuk, Zephaniah, Haggai [Grand Rapids: Eerdmans, 1950; ET from Latin by John Owen], 360. Even Hengstenberg denies a messianic interpretation (except in an attentuated, ultimate sense) to $\mathrm{Hg}$ 2:6-9. Hengstenberg explicitly follows Calvin and adds further arguments of his own (Christology of the Old Testament, vol. 2 [Florida: MacDonald Publishing Co., nd; reprint of ET of 1854 from German of 1829], 931-53, esp. 942-51). Hengstenberg may not be entirely consistent, however, for in his concluding appendices he states the messianic nature of Haggai more strongly than in his detailed exposition ('Haggai... in chap. ii. 1-9 points to the completion of the kingdom of God in Christ' [1261]). 
resources of Christian faith in the kind of way that might appropriately address the situation. Instead Pusey could only fall back on a patristic traditionalism with a kind of woodenness (and rationalism of his own) that signally failed to display the true depths of Christian tradition. 10

It must also be said that evangelical scholars have not always seen how to move beyond Pusey's impasse. ${ }^{11}$ If one consults the NIV on Haggai 2:7, one finds 'and the desired of all nations will come, and I will fill this house with glory'. I find it difficult to see what the reader is meant to understand by 'the desired of all nations'; 'the desired what?' is the obvious question. My suspicion is that the translators have opted for this rendering, with its lack of clear meaning, precisely in order to leave open the traditional messianic construal of the text, even though it can only fit in a forced way with the contextual concerns of Haggai. That is, the translators' own stated 'first concern' of 'fidelity to the thought of the biblical writers' 12 appears to have been overridden by a kind of messianic theology that, despite its ancient precedents, does not in fact display 'fidelity to the thought of the biblical writers'. In other words, there may be justification for the concern of some biblical scholars that the NIV sometimes skews philology and history in the interests of theology, in just the kind of way that was discredited in the 19th century. ${ }^{13}$

10 Of course, the Fathers too can not infrequently be problematic, for they can allow appeal to the Spirit to override philological and historical argument; see, for example, many of the arguments for the status and value of the LXX as conveniently set out in Martin Hengel, The Septuagint as Christian Scripture (Edinburgh \& New York: T \& T Clark, 2002; ET from German by Mark Biddle), ch. 2. The abiding value of the Fathers lies, inter alia, in their overall sense of the nature of theology and scriptural interpretation as prayerful enterprises within the context of the life of faith.

11 Indeed some would resist the way I have construed the problem in the first place. See e.g. Walter C. Kaiser, Jr., The Messiah in the Old Testament (Grand Rapids: Zondervan, 1995) for an overall hermeneutic of OT messianism, which includes a defence of $\mathrm{Hg}$. 2:7 as referring to the Messiah (206-209). Kaiser's argument is better set out than Pusey's, but I cannot find it more persuasive.

12 From the preface to the NIV.

13 The translation principles of the NIV are set out in K. Barker (ed.), The Making of a Contemporary Translation (London: Hodder \& Stoughton, 1987). Although there is no reference to Hg. 2:7, Bruce Waltke's 'Translation Problems in Psalms 2 and 4' (117-26) is illuminating. Waltke says: 'With a high view of the text's inspiration by one Author, the NIV translators sought to harmonise the Old Testament (OT) with the New Testament (NT) as much as possible (where the textual and lexical evidence would allow for it)' (118). The big questions, of course, are a) what is, and is not, entailed by a belief in divine inspiration, b) what is proper and improper harmonisation, c) what is the scope of, and the controls upon, a text 'allowing for'. With regard to the construal of the royal son in Ps. 2, Waltke concludes: 'Although on the historical level one might rightly opt for 
Against this background, a certain humility on the part of the would-be theological interpreter of Scripture is not out of place. It is of prime importance, if we are not to repeat old mistakes, to be able to draw appropriately upon the rich resources made available by recent hermeneutical debate, resources already helpfully mapped and made accessible to the non-specialist. ${ }^{14}$ For this can enable the rethinking of the categories whereby we interpret Scripture, in the kind of way that can make the appropriate retrieval of classic Christian concerns more possible. 15 The enormous potential of our contemporary context is well described by David Tracy:

The hermeneutical tradition from Heidegger through Gadamer and Ricoeur defends the primordial notion of truth as event of manifestation... The primary advantage is that the notion of truth as manifestation (and recognition on the side of the subject) more closely fits both notions of revelation as event of God's self-manifestation and the response of faith as gifted recognition. The truth of religion, like the truth of its nearest analogue, art, is primordially a truth of manifestation (more exactly, disclosure-concealment and human recognition). Hermeneutical thought, with its philosophical and non-romantic defence of truth as manifestation, is well suited to defending anew this primal insight of both art and religion. In that sense hermeneutical thought is useful for reopening the highly complex philosophical and theological questions of the nature of revelation and the graced response of recognition named faith. ${ }^{16}$

rendering the references to the king by lower case, on the canonical level one rightly opts for upper case, as in the NIV text. By using upper case in Psalm 2 the NIV translators expose their orthodox views not only of inspiration but also of christology' (125). Whether this appeal to 'canonical level' and 'orthodox views' appropriately resolves the many and complex theological and hermeneutical issues is to my mind doubtful.

14 Amidst the mass of literature, see esp. Anthony C. Thiselton, New Horizons in Hermeneutics (London: HarperCollins, 1992), and Sandra M. Schneiders, The Revelatory Text (2nd ed., Collegeville: Liturgical Press, 1999).

15 My recent The Bible, Theology, and Faith: A Study of Abraham and Jesus (Cambridge Studies in Christian Doctrine; CUP: 2000) is in effect an essay on this theme. See also my 'How Can We Know Truth? A Study of John 7:14-18' in Richard Hays \& Ellen Davis (eds.), The Art of Reading Scripture (Grand Rapids: Eerdmans, 2003) forthcoming.

16 'The Uneasy Alliance Reconceived: Catholic Theological Method, Modernity and Postmodernity' in J. Webster and G.P. Schner (eds.), Theology After Liberalism: A Reader (Oxford: Blackwell, 2000), 335-57 (346-47). 


\section{The Problem of Conceptualizing Revelation within the Old Testament: The 20th Century Example of Preuss}

The difference which may be made by engaging with current hermeneutical thought can perhaps usefully be considered in relation to a relatively recent work which does not do so. The two-volume Old Testament Theology by Horst Dietrich Preuss ${ }^{17}$ to my mind illustrates all too clearly why German biblical scholarship no longer leads the field as it did for some two hundred years; for (despite the blurb on the dust jacket about 'utilising the most recent scholarship available') none of the fresh considerations which have enriched recent scholarly work, such as narrative theology, canonical approaches, figural interpretation, feminist perspectives or ideological critiques are allowed to disturb an older 'historical-critical' approach to the text. ${ }^{18}$ Although in many contexts it may well be appropriate to appeal to the well-tried and time-honoured as opposed to the passing fashions of the day, such an appeal even at its best must retain the kind of self-critical awareness that prevents it from falling into a narrowing complacency; and it must continue to show its justification by its fruitfulness.

Preuss, like probably all who set their hand to an OT Theology (as distinct from a history of Israelite religion, or Tanakh theology), writes as a Christian believer. ${ }^{19} \mathrm{He}$ is clear that his Theology is designed to contribute to 'the larger structure of Christian theology... contemporary, theological debate... contemporary proclamation and religious instruction'.20 Yet the question of how the pre-Christian writings of the OT should be able to do this does not greatly concern him, beyond his insisting upon the well-worn claim that the enterprise must remain 'a historically oriented as well as a descriptive

17 Edinburgh: T \& T Clark, 1995; ET by L.G. Perdue from German of 1991.

18 A useful overview of Preuss's work is provided by Barr in his Concept, 46167. Barr is generally positive about Preuss, though with some telling criticisms. He sees Preuss's work as 'an affirmation and a continuation of that classic line which began with Eichrodt' (464), which 'fully equals the massiveness of the older works, and may well have succeeded in avoiding some of their weaknesses' (467). 19 Some of the potential problems with this are memorably set out by Jon Levenson in his 'Why Jews Are Not Interested in Biblical Theology' in his The Hebrew Bible, The Old Testament, and Historical Criticism (Louisville, KY: Westminster/John Knox, 1993), 33-61. Preuss could probably weather Levenson's strictures better than many, because of the proximity of his enterprise to a certain kind of history of Israelite religious concepts and beliefs.

20 Theology, 20. 
undertaking'21 in the context of his offering an account which revolves around divine election and human obligation as an appropriate 'center' of OT theology. Although he asks questions such as 'How does the Old Testament speak of God, that is, how is "theology" expressed? How does the OT present God as speaking and being spoken to? What is the basis that makes this type of language possible?', 22 he sees these questions as to do with how to depict the content of the OT within its own context.

For example, Preuss introduces his discussion of the obviously important theological issue of 'revelation' thus:

It should not be overlooked that we have in the Old Testament texts only words about revelations of God, but not the actual revelations of God themselves, even when the evidence of the Old Testament text treats the self-revelation of God. What we do have are texts that give information about revelation(s) in very different ways, and these texts are still written mostly, not by those who were participants in these 'revelations', but by later witnesses. [A footnote at this point adds:] Moreover, it is valid to say that revelation 'is no objective, comprehensible phenomenon but rather a personal experience that befalls human beings' (G. Fohrer). [The text then continues:] Also, this is not the place to ask whether and to what extent the Old Testament as a whole is to be classified as the revelation of God; rather, it is the place to inquire about the discussion of revelation(s) in and according to the witness of the Old Testament. ${ }^{23}$

These words merit some detailed consideration. To take the last point first, Preuss considers questions about the status of the OT itself 'as the revelation of God' to be out of place. He seems to assume the kind of division of labour which has been all too common in modern biblical criticism, whereby questions about the nature of Scripture are the work of the systematician rather than the exegete. There are, of course, obvious pragmatic justifications for this kind of division, ${ }^{24}$ yet it can perhaps too easily encourage biblical scholars to operate in an unduly narrowed kind of way (though of course the exceptions to such a generalization are numerous, not least such giants of the discipline as Bultmann and Käsemann, von Rad and Childs). ${ }^{25}$

\footnotetext{
21 Theology, 20.

22 Theology, 23.

23 Theology, 200.

24 Gabler's famous programmatic distinction between biblical theology and dogmatic theology still assumed that the two tasks should be sequentially connected. It was only subsequently that the distinct tasks drifted apart until, for example, Wrede could programmatically assume a great gulf between them.

25 Even for good historical work (irrespective of questions of theology), there must necessarily be a dialectic between the interpreter's grasp of life in the present and their construal of what took place in the past (as indeed good historians recognize). Issues of understanding are not solely subsequent to establishing a
} 
Preuss' Christian assumption that his work should contribute to the wider task of Christian theology surely makes pressing the question of precisely how the content of the OT can make its contribution to Christian theology; not least because Christian theology entails contexts which by definition are other than those in which the texts were both composed and compiled, and envisages responsible use in these contexts. As David Kelsey puts it: "The expression "Scripture is authoritative for theology" has self-involving force. When a theologian says it, he does not so much offer a descriptive claim about a set of texts and one of its peculiar properties; rather, he commits himself to a certain kind of activity in the course of which these texts are going to be used in certain ways' ${ }^{26}$ Preuss's cited words acutely raise the question of how a text, purportedly about divine selfrevelation, which is apparently a) a distantly second-hand account of b) something perhaps intrinsically incommunicable anyway and which is c) conceived in pre-Christian categories, is to be used constructively in contemporary Christian theology. Preuss clearly assumes that that is someone else's problem. But whose?27 What if it is properly his problem, on the grounds that the complex issues require a grounding

historical account of the text and its content in its own terms, but are in certain ways inseparable from, even antecedent to, offering a good account in the first place. See the fine account with reference to biblical interpretation of Nicholas Lash, 'What Might Martyrdom Mean?' in W. Horbury \& B. McNeil (eds.), Suffering and Martyrdom in the New Testament (CUP: 1981), 183-98; reprinted in Ex Auditu 1 (1985), 14-24, and in Lash, Theology on the Way to Emmaus (London: SCM, 1986), 75-92.

26 The Uses of Scripture in Recent Theology (London: SCM, 1975), 89.

27 Compare the remarks with which Preuss concludes his work: 'The discovery and the development of these fundamental structures of Old Testament faith, however, cannot remain only historically oriented and purely descriptive [i.e. Preuss' own work needs something further]. Old Testament theology shall have to join in the endeavour within Christian theology to produce a 'biblical theology', which perhaps likewise is to search for the common fundamental structures of its witnesses as well as for its structural analogies, in order for the Christian faith to receive and keep its significance...' (Theology $I$, 307). With regard to the questions of who might be in a position to do this, and how it should be done, Preuss has already stated at the outset: "the "Theology of the Old Testament" is understood to be that theology which the Old Testament itself contains and presents, and not a theology that has the Old Testament as a subject of study [in my judgment, this familiar dichotomy begs numerous questions]. This latter understanding belongs more to contemporary hermeneutics or fundamental theology' (Theology I, 1; my italics). How contemporary hermeneutics or fundamental theology should rightly use the kind of historical material Preuss has provided is never addressed. I am reassured that I have not missed something in Preuss when Barr similarly comments: 'On the question of how the Old Testament is to be treated within this other "biblical theology" he seems to offer no suggestion' (Concept, 464). 
in the technical issues of OT interpretation such that an OT scholar specializing in 'theology' might reasonably be expected to have-for if the specialist does not tackle these questions, then who can and will? The scholar who might reasonably be exempted is the scholar who is not concerned whether or not their work contributes to Christian theology, not the scholar who makes Christian concerns explicit.28

The second issue, in Preuss's footnote, is the very nature of 'revelation' as 'no objective, comprehensible phenomenon but rather a personal experience that befalls human beings'-or, better, 'no objectively graspable phenomenon but rather a personal experience that concerns human beings' ${ }^{29}$ Given that, in the words of Tracy already cited, revelation raises 'highly complex philosophical and theological questions', it is remarkable that Preuss somehow considers it sufficient to offer no philosophical or theological discussion of the concept whatever, but rather to cite a one sentence account by a fellow biblical scholar whose philosophical and theological credentials are hardly different from his own. There is also something prima facie surprising in a Christian commending such an account of revelation. For in the terms of historic Christian theology the content of faiththat which is revealed-is indeed a mystery. But it is a mystery not in the sense of a puzzle awaiting resolution but in the sense of a truth which is such that 'the more you know, the more you know you don't know'.$^{30}$ Additionally, despite the need for personal transformation in order rightly to comprehend and appropriate the mystery, the mystery is still understood to be public and shared, as expressed in Scripture and the creeds, and in no way esoteric or private (as though the Bible promoted a kind of equivalent of the Eleusinian mysteries). ${ }^{31}$

28 Preuss notes Childs' claim that 'The theology of the Old Testament is combined with Old Testament hermeneutics' but evades Childs' concerns by simply focussing on whether or not such hermeneutics might skew accurate depiction of the OT on its own terms: 'Whether this is an enhancement for the actual theology of the Old Testament or potentially diminishes the description is a question that remains to be answered' (Theology, 18).

29 Offenbarung 'ist keine objektiv fassbare Erscheinung, sondern ein persönliches Erleben und Erfahren, das den Menschen betrifft' (Fohrer). Perdue's translation misses the adverbial sense of 'objektiv' and weakens the force of 'betrifft'.

30 So, for example, Paul prays for the Ephesian Christians to know the love of Christ which surpasses knowledge (Eph. 3:19).

31 One might compare the fact that for St Paul the astonishing experience of God that he had, where he heard 'inexpressible words, which a human may not speak', is clearly subordinated to the thorn in the flesh and the accompanying divine message which is fully communicable, 'My grace is sufficient for you, for power is made complete by weakness' (2 Cor. 12:1-10). 
Rather than try to plot on an intellectual map Preuss's polarizing of 'objectively graspable phenomenon' over against 'personal experience that concerns', it may be more helpful instead to look at one recent discussion of the nature of revelation. Rowan Williams' essay, 'Trinity and Revelation', is germane not least because Williams gives attention to both Old and New Testaments in the context of formulating his account. ${ }^{32}$ Williams' overall concern is to escape from an account of revelation which short-circuits the process of human learning necessary for understanding what divine revelation does, and does not, mean. That is, he wants to resist 'a model of truth as something ultimately separable in our minds from the dialectical process of its historical reflection and appropriation'; for the alternative, that is 'to begin from a sense of achievedness, consummation' in such a way as to downplay issues of human learning and appropriation, 'undermines its [sc. revelation's] own claim to be able to speak with authority to an experience of conflict and fragmentation, to the historical aspiration and work of men and women' (132). Throughout the essay Williams makes positive use of the work of Ricoeur (whose significance is also highlighted by Tracy). More specifically, Williams argues:

Revelation ... is essentially to do with what is generative in our experience-events or transactions in our language that break existing frames of reference and initiate new possibilities of life... [Revelation] poses fresh questions rather than answering old ones. And to recognize a text, a tradition or an event as revelatory is to witness to its generative power. It is to speak from the standpoint of a new form of life and understanding whose roots can be traced to the initiating phenomenon. And we might add that-as an obvious corollary-when there is no longer a felt need to use the category of revelation, this can be attributed to an atrophying of the sense of belonging in a new world. Put in directly religious terms, it is the withering of anything that might be called an experience of grace, and a loss of confidence in the human worthwhileness or hopefulness of life in grace.

Thus 'revelation' is a concept which emerges from a questioning attention to our present life in the light of a particular past-a past seen as 'generative'. In terms of the scriptural history of Israel, the events of the Exodus were revelatory insofar as they were generative of the community of Israel itself; and Torah was revelatory because it was what specified the form of life of that community ...

Any theology of revelation is committed to attending to event and interpretation together, to the generative point and to the debate generated. And, if this is a correct analysis, the model of revelation as a straightforward 'lifting of a veil' by divine agency has to be treated with caution ... The language of veil-lifting assumes a kind of passivity on the part of the finite

32 Rowan Williams, 'Trinity and Revelation' in his On Christian Theology (Oxford: Blackwell, 2000), 131-47. 
consciousness which abstracts entirely from the issue of the newness of the form of life which first prompts the question about revelation. 'Is this event revelation?' is only a question that can be asked on the basis of the wider question: 'If we live like this, has revelation occurred?'33

Whatever further might still be said about revelation, ${ }^{34}$ Williams makes at least two things clear. On the one hand, the assumption (apparent in Preuss) that revelation is a notion not requiring careful analysis in its own right is simply untenable. On the other hand, an insistence on the mutual and reciprocal nature of revelation and response points to a way in which, as we will see, we can make better sense of the biblical text.

Finally, for this discussion of Preuss's formulation, there is his initial point: 'We have in the Old Testament texts only words about revelations of God, but not the actual revelations of God themselves... and these texts are still written mostly, not by those who were participants in these "revelations", but by later witnesses'. This formulation echoes the language of 17th and 18th century deism, and clearly has negative implications about the status of what the biblical text presents as the self-revelation of God. The combination of 'only words about revelations of God' with 'by later witnesses' poses the key question of the genre and status of the text. For Preuss, as for many others, the biblical text appears as a kind of ancient history manqué; the distance between the context depicted within the text and the context of the author responsible for the text is often so great (centuries in the case of pentateuchal narratives) that the use of the text becomes highly problematic. The robust theological use of the text by premoderns, ${ }^{35}$ unaware of the historical problems, is ruled out for the responsible modern interpreter.

33 'Trinity', 134f.

34 John Webster, for example, thinks that Williams says too little about the direct personal agency and presence of God ('Hermeneutics in Modern Theology: Some Doctrinal Reflections' in his Word and Church: Essays in Christian Dogmatics [Edinburgh \& New York: T \& T Clark, 2001], 47-86 (67); reprinted from SJT 51 (1998), 307-341.

35 So, for example, to anticipate with an example of robust premodern usage of Ex. 34:6-7, one might note Benno Jacob's appreciative citation of Martin Luther: 'They [Ex. 34:6-7] have been a leitmotif of the Jewish penitential prayers...and form the foundation of the countless $s^{\prime} l i$-hot composed through centuries. The repentant people of Israel have used these thoughts to plead to HIM with complete contrition, ardor, and zeal. Luther, who reflected upon the synagogue of the fifteenth and sixteenth centuries, stated: 'I would give two hundred golden guilders if I could pray like the Jews. They have learned it from the magnificent prayers of their teacher Moses, and he was taught by God Himself!' (Exodus [Hoboken, NJ: Ktav, 1992; ET by Walter Jacob from unpublished German of 
We will take this issue further in the course of developing our own proposal. In general terms, however, it seems clear that for Preuss, to use the phrasing of Chris Seitz, ${ }^{36}$ Scripture has become Religion; or, in other words, the scriptural text has ceased (for the most part) to be a holy writing that reveals and has become instead (for the most part) a historical record of what was considered revelation in ancient Israelite religion, with no proper dialectical interaction between these two understandings. Questions to do with the human knowledge of God, as focussed in 'revelation', are treated as problems of historical depiction for what was the case in Israel, with no engagement with historic and contemporary use of the text in relation to knowledge of God through the medium of the text (even if the enduring significance, in some way or other, of what the biblical text says is clearly assumed). If Old Testament, or Biblical, Theology is to have a future, then it must be able to do better than this.

\title{
Biblical Theology and Truthful Speech about God: Exodus 34:6-7 and a 21st Century Proposal
}

\begin{abstract}
YHWH passed before him [Moses], and proclaimed, 'YHWH, YHWH, ${ }^{37}$ a deity gracious and merciful, slow to anger, and abounding in steadfast love and faithfulness, keeping steadfast love for thousands, forgiving iniquity and transgression and sin, but who will by no means clear the guilty, visiting the iniquity of the fathers upon the children and upon the children's children, to the third and the fourth generation. (Exodus 34:6-7, my translation)
\end{abstract}

Rather than discuss issues in the abstract, or with generalizations about the OT that are likely to admit of numerous exceptions, I propose to focus on one key text, which raises almost all the major issues: Exodus 34:6-7. I will set out my own proposals initially in interaction with Preuss's account, so as to try to clarify the nature of the difference between us.

Preuss discusses Ex. 34:6-7 in a general section about 'the "Nature" of Yahweh'.38 Although the section is prefaced with the valuable observation that the OT speaks about the nature of God not

c.1940], 985). Unfortunately Jacob does not give the source of the quotation, and I am not able to trace it.

36 See above, n. 7.

37 I follow the masoretic punctuation, but am still undecided as to whether or not it represents the best construal of the text.

38 Theology, 239-49. 
'in and of itself... but rather his relationship to human beings', this is only utilized to issue a familiar call for historical purity-'one should be careful about the use of later philosophical, theological categories of thought to set forth the Old Testament's view of reality (e.g., "aseity")'-not to spur constructive engagement with the dialectics of revelation and response either within the text or within the relationship of text and interpreter.

Preuss's specific discussion of Ex. 34:6-7 is in two sections (parts of which I will cite below). ${ }^{39}$ On the one hand, there are some general comments about the redaction and tradition-history of the text which is construed as an originally independent formula, with occasional comments about ancient Near Eastern analogues. On the other hand, Preuss discusses general OT usage of some of the key words in the verses. For the sake of argument, let us grant Preuss's analytical observations about the text. ${ }^{40}$ What then is wrong with his discussion as a contribution to OT theology?

First, there is the astonishing abstraction of the text from its narrative context, which receives no more notice than a redactional speculation ("This "formula of grace" (H. Spieckermann) perhaps was first inserted into the context of Exodus 34 in connection with apostasy, the confession of guilt, and later the formation of the commandments'). Even so the context is misconstrued, for nothing adequate $^{41}$ is said about the intercession of Moses which, after the apostasy, sets the scene for the divine self-revelation. That the present narrative context might in fact be the prime context for understanding the meaning of the 'formula of grace'-i.e. that it is where it is precisely so that it may best be understood-is a notion entirely absent from Preuss. ${ }^{42}$ In other words (to put what might be a purely literary point in theological categories), it is indeed valid for the ancient

39 Theology, 241-43.

40 There is much that is open to debate. For example, that Ex. 34:6-7 'presupposes Jeremiah and Deuteronomy' has indeed been argued by other scholars; but it is the kind of history-like claim that is hardly more than an impressionistic construal of one possible relationship between texts whose precise dating and tradition-history eludes us.

41 Preuss's 'confession of guilt' is presumably a reference to Ex. 32:31, but is wholly inapplicable to the content of Moses' prayers in 32:11-13 and, most crucially of all in context, 33:12ff.

42 At Preuss's time of writing literary arguments for narrative as meaningful in itself and canonical arguments for attending to the received form of the text were already well established within biblical scholarship. I do not know why Preuss chose to neglect them. His comments on Childs (Theology, 17-18) are not greatly illuminating. 
historian to use the text as a source for recovering aspects of tradition and history older than itself (though whether we will ever be able to date the text, never mind its possible antecedents, with any justified degree of confidence seems ever less likely, despite the intensive work of the last two centuries which still continues); nonetheless, for the theologian it is vital to work seriously with the biblical narrative in its own narrative integrity, as witness to, or refraction of, a moral and spiritual reality beyond itself. 43

Secondly, a consequence of loss of narrative context is imaginative impoverishment. Preuss introduces his discussion: 'A small compendium of statements about YHWH's form and nature, found rather seldom in the Old Testament, comprise the formula (shaped by JE) in Exod. 34:6f. that perhaps should be understood in its context as a self-predication of YHWH'. One would hardly know from this what is apparent to the careful reader of the biblical text itself. This is the fullest depiction of the name and nature of God within the whole Bible (Old and New Testaments together); the words are clearly set on the lips of YHWH Himself, ${ }^{44}$ thereby indicating the divinely-given origin of their content; the unparalleled cumulation of terms of mercy and forgiveness is a response to Moses' intercession in a context of Israel's paradigmatic apostasy; the divine words are spoken to Moses alone as privileged recipient, as in Exodus 3; the setting is the foundational holy context of Mt Sinai, where Israel receives its definitive torah and self-understanding as the people of YHWH.

This imaginative impoverishment means that the portrayal within the text is not taken with total seriousness in its own right, because it is too quickly transposed into other categories. This matters not least because of the nature of revelation. If, as Tracy says, religion has important analogies to art, and divine self-revelation involves a manifestation which requires a particular kind of human responsiveness analogous to being able truly to see what a picture portrays or hear what a piece of music conveys, then it is surely important to approach the Bible as one would a great work of art:

43 Hans Frei, The Eclipse of Biblical Narrative (New Haven \& London: Yale UP, 1974) remains a foundational literary-cum-theological argument about the nature of narrative interpretation.

44 The Hebrew of Ex. 34:5-6 could allow either YHWH or Moses to be speaker of the crucial words about the nature of YHWH (i.e. the subject of wayyiqrâ' in v. $6 \mathrm{a})$, and so the words in another context might not have YHWH as their subject. Nonetheless, within the present narrative context of Ex. 32-34, the context-setting Ex. 33:19 indicates that YHWH is to be understood as the speaker, as does the citation of this passage in Nu. 14:17-18. 
something before which one lingers long and ponders expectantly, with that particular kind of openness which is called prayer. ${ }^{45}$ The analytical considerations which one may properly bring to bear upon the construction and genre of the work of art should serve to enable one's deeper appreciation rather than to displace attentive openness. Yet possible response to the biblical text's portrayal is hardly capable of being an option in Preuss's account.

Thirdly, Preuss offers no substantive engagement with the content, the subject matter (Sache, res) of the text. What Preuss says about the key terms in the text may be accurate as far as it goes-for example, "Gracious" (hannûn) designates the grace and favor of a highly placed person, who, for example, like a king, hears a plea and condescends to the lowly'-but it does not go very far. As I read Preuss, Barth's famous account of biblical interpretation in the Preface to the second edition of his Romans commentary comes to mind:46

My complaint is that recent commentators confine themselves to an interpretation of the text which seems to me to be no commentary at all, but merely the first step towards a commentary... By genuine understanding and interpretation I mean that creative energy which Luther exercised with intuitive certainty in his exegesis... how energetically Calvin, having first established what stands in the text, sets himself to re-think the whole material and to wrestle with it, till the walls which separate the sixteenth century from the first become transparent! Paul speaks, and the man of the sixteenth century hears. The conversation between the original record and the reader moves round the subject-matter, until a distinction between yesterday and today becomes impossible... Criticism (krinein) applied to historical documents means for me the measuring of words and phrases by the standard of that about which the documents are speaking - unless indeed the whole be nonsense.

The fact that Barth's programme may require further qualification and nuance in formulation, and that his handling of Romans is indeed open

45 In discussion Gerald Bray pointed out that Tracy's appeal to the analogy of art says nothing about the concept of a word to be heard, and so might be considered deficient. I wonder, however, whether any sharp antithesis between seeing and hearing is not largely overcome in the actual practice of scriptural interpretation, since the construal of the words on the page whose content one seeks to hear involves the discernment of patterns of language, imagery, narrative construction, etc. comparable to what is involved in looking at a picture.

46 Karl Barth, The Epistle to the Romans (OUP: 1968; ET from 6th German ed. by Edwyn Hoskyns), 2-15 (6, 7, 8). It is notable that Preuss evokes the same thought within James Barr: 'We cannot avoid at times the feeling that it [Preuss's book] presents us with the necessary material for a theology rather than a theology itself. This is of course no new criticism, and was classically stated by Karl Barth about critical scholarship in general. But in Preuss's work it seems at least in places to be valid' (Concept, 466-67). 
to question in various ways (not least whether the first century context and meaning of Paul is always sufficiently respected), does not mean that the challenge of his vision of interpretation should be evaded. In other words, a text such as Exodus 34:6-7 requires the kind of moral and theological literacy that can enable an account of grace, mercy and forgiveness to be not just moral and religious words but a portrayal of amazing realities which are fundamentally constitutive of true knowledge of God. 47

Fourthly, it is important to see that the fundamental claim of the text-that the merciful nature of God is a reality made known and accessible to Israel by God Himself - cannot be adequately addressed by the kind of historical considerations which Preuss rehearses. To be sure, an awareness that the text was probably written centuries later than the time of Moses, and that possibly complex traditio-historical developments underlie it, requires an understanding of the genre of the text different from that which characterized almost all premoderns who simply assumed that Moses wrote it. Yet on any reckoning, there is human agency involved in the composition of the text, whether of Moses himself or of anonymous tradents. The recognition of human agency and processes should not be set in competition with an account of divine agency, for the characteristic biblical model is that God works in and through human agents. That is, just as many and complex human processes need not preclude divine initiative and overruling, so relatively simple human processes do not guarantee it; for it would be perfectly conceivable to think that Moses wrote the text, no doubt after a series of remarkable experiences, but that his ascription of words and actions to God was a fantasy and selfdelusion. In other words, to recognize human imagination and construction at work in the formation of the text is not incompatible with recognizing an antecedent divine reality which enables and constrains that work of construction. ${ }^{48}$

47 In a related way, Martin Buber had the ability often to be a profound interpreter of the Bible perhaps because he was primarily not a biblical scholar but a thinker concerned with enduring issues about God and human life. For example, in his Two Types of Faith (London: Routledge \& Kegan Paul, 1951), there is much to disagree with. But consider part of his discussion of Is. 28:16: 'All through the Old Testament to believe means to follow in the will of God, even in regard to the temporal realization of His will: the man who believes acts in God's tempo. (We only grasp the full vitality of the fundamental Biblical insight when we realize the fact of human mortality over against God's eternity.)' (22).

48 It is for this reason that one needs to rethink a characteristic emphasis of much evangelical OT scholarship over the last hundred years, which is well expressed by Alec Motyer: 'If...the Pentateuch is long post-Mosaic and much of it post- 
This conceptual point of course cannot disqualify specific historical questions about the nature of the human processes involved in the formation of the text. In general terms, it would seem to be important that the human processes are not envisaged in such a way as to negate that divine reality which they mediate, i.e. human integrity within the formation of the textual tradition matters (processes marked by consistent brutality, deception, or manipulativeness would by their very nature be incapable of faithfully mediating a divine reality of steadfast love and mercy); though even here, the biblical conception of divine election of the stiffnecked suggests that one should resist any easy moralism. The real historical difficulty, however, is ignorance. We simply do not know nearly as much as we would like (numerous learned and detailed monographs notwithstanding) what went on in either the formation and composition of the text, or in its reception and canonical compilation. Although modern scholarship has generally (though not all are persuaded) established the negative conclusion that premodern ascriptions of pentateuchal authorship to Moses, and perhaps canonical appropriation to Ezra, cannot be maintained in historiographical terms, positive historiographical proposals are many, varied, and constantly contested. Scholars are necessarily constrained to hypothesize ancient Israelite processes in terms of their overall vision of what characterizes religious texts and communities both ancient and modern (so we return to the question of the adequacy of the interpretative categories whereby one construes the content of the text).

One possible approach, taking a lead from Childs, is to see the processes both within the formation of the biblical texts and within their reception and compilation as essentially religious or theological-a process of sifting and discernment, on the part of unknown but religiously responsible and theologically aware tradents, so as to constitute Israel's traditions in such a way that they would be most enduringly accessible to subsequent generations of (would-be) observant/faithful Israel; the historical depth behind the text gives its received form a kind of lived wisdom and existentially tested truth. Some other scholars tend rather to emphasize social and political factors, as in Gottwald's taking for granted that Israel's traditions in the processes of transmission and reformulation 'served over the centuries as ideological ammunition in political infighting' 49 Although I consider the kind of conceptuality associated with the former approach more appropriate than the latter, I do not see how one can adjudicate between them in so far as each is understood to be making a historical claim, since the same limited evidence is clearly patient of widely divergent construals.

The issue is at heart one of heuristic models. It is therefore important that the heuristic categories are not defined in the kind of narrow way that simply invites qualification or dissent. That is, it would be unwise to define 'theological'

exilic, it has become totally detached from the actual history of the Exodus and, exacerbating the situation, the more the historicity of the Exodus events is viewed with scepticism, the less the doctrinal statements of the Pentateuch possess the quality of objective revelation. God and the acts of God are no longer at their root, and all that can be said is that this or that "truth" is what people happened to believe at certain points in the history of Israel. Theology has been replaced by believing' (Look to the Rock [Leicester: IVP, 1996], 15). The oversimple polarization of history and objectivity over against (mere, subjective) believing falls into the inappropriate use of Enlightenment categories which put apart what should be held together; it obscures both the nature of the objectivity that characterizes divine revelation and what is involved in human reception and appropriation of that revelation.

49 Norman K. Gottwald, The Politics of Ancient Israel (Louisville: Westminster John Knox, 2001), 162. 
processes in the kind of way that excluded 'political' factors (and vice versa). 50 No comprehensive programme for the identity and lifestyle of a people, such as the OT in certain ways represents, could possibly be implemented without wideranging social, economic and political action. And that the process might in certain respects have been abrasive and bruising would seem only likely in view of the conflicts repeatedly depicted within the canonical texts themselves; when things in life that matter are at stake, disagreements àre rarely resolved simply or painlessly. Comprehensive programmes require that some people are persuaded to embrace and appropriate the content of the programme, while others are persuaded at least to acquiesce in it. However the sheer paucity of evidence does make it difficult to see how one could make substantial progress in this kind of discussion as regards the OT.

Perhaps the most difficult issues are those posed by the very form of the text's portrayal of God. God is a speaking, acting agent within the text, a character in certain ways analogous to other characters. It is this 'anthropomorphic' portrayal of God which both gives the OT narrative its engaging and accessible qualities and makes it potentially problematic in a variety of ways, as the history of reception and interpretation makes so clear. Despite recurrent desires on the part of both Jews and Christians to transpose the portrayal of God into other, usually more abstract, categories, the real challenge is to take the portrayal with total seriousness but without handling its language woodenly or literalistically, as though claims about history or ontology could be read off from it without more ado.

All this brings us back to the issue of how claims to, or depictions of, divine revelation should be understood, an issue which for the Christian (and probably also, I guess, for Jew or Muslim) is not answerable without some account of that human responsiveness which Christians call faith. So we return to Rowan Williams' thesis that we should think of revelation as that account of God which is generative of a new form of life which is undergirded by grace, wherein what is ascribed to God as an ontological reality cannot be so ascribed in isolation from a human responsiveness which is required to learn over time what is the true nature of that divine reality of which it seeks truthfully to speak. If this is on the right lines, then it would apply both with regard to how we should conceive the formation and canonizing of the text itself, and with regard to how we should conceive our contemporary reception and appropriation of it.

50 Gottwald's Marxian critique of religious idealism (The Tribes of Yahweh: A Sociology of the Religion of Liberated Israel 1250-1050 BCE [London: SCM, 1980], 591ff.) needs to be heard and felt even by those who find Gottwald's own programme reductive or otherwise unsatisfactory. 
Finally, a few brief exegetical and interpretative observations to complement our more general remarks about the interpretation of Exodus 34:6-7.51

First, in general contextual terms, it is the intercession of Moses, subsequent to Israel's sin and YHWH's wrath, which prepares the way for the divine self-revelation. At least two things are significant here. On the one hand, it is only when Moses intercedes that God reveals. ${ }^{52}$ The implication is that self-involvement makes possible an encounter with, and fuller knowledge of, God that a self-distancing would impede; in other words, certain kinds of 'objectivity', in which the knower tries to keep distance and distinctness from what is known, rule out the kind of knowing of God which is the foundation of biblical and Christian faith. On the other hand, Israel's sin with the golden calf while still at Sinai, a transgression of the first two commandments-whose significance is somewhat akin to adultery on one's wedding night - might naturally lead the reader to expect only divine wrath and judgment (as predominantly in 32:7-35). The context thus underlines the astonishing and not-to-be-taken-forgranted nature of the divine mercy. In other words, grace is amazing, and if it ceases to be perceived as surpassing expectation then something integral to its true nature is lost.

Secondly, the divine speech ${ }^{53}$ in response to Moses' intercession in 33:19-23, sets the specific context for Moses' fresh ascent of Sinai. The promise that YHWH will proclaim His name before Moses and concurrently reveal His grace and mercy (v. 19), is followed by the placing of a limitation on Moses' seeing God (v. 20) and an account of how YHWH will cover Moses while He passes by, in such a way that Moses will only see YHWH's back and not His face (vv. 21-23). The coming divine self-proclamation is thus linked with the partial and restricted nature of what Moses will be able to see. Thus the fullest account of the name and nature of God in the whole Bible (34:6-7) is preceded by an emphasis upon the limitation of what the

51 Although I would still maintain the exegesis and interpretation in my At the Mountain of God: Story and Theology in Exodus 32-34 (JSOTSS 22; Sheffield: JSOT, 1983), ch.2, I think it could be expressed better and there are dimensions of the text which I think I now see more clearly.

52 The intercession of Moses in Ex. 33 is not dissimilar to the questioning of Moses in Ex.3 which sets the context for the divine self-revelation in 3:13-15.

53 The speech formula, 'and he said', in 33:20, 21, 34:1 when YHWH is already speaking, functions as a marker to separate the different elements within what YHWH says, somewhat analogously to modern paragraphing; cf. my The Old Testament of the Old Testament (OBT; Minneapolis: Fortress, 1992 [repr. Wipf and Stock, 2001]), 18 n. 19. 
privileged recipient is able to receive. It implies that 'seeing' God is not a matter of focussing with the eyes but being exposed to, and being able to receive, a certain kind of gracious reality. Moreover, the text is surely, in its own way, articulating that sense which has been fundamental to classic theology that to know God is to know the one who surpasses knowledge ('the more you know, the more you know you don't know'). This dynamic preserves the true nature of knowing God, for such knowing rules out both complacent or arrogant overconfidence ('we know all there is to know about God') and disheartened ignorance or complacent agnosticism ('we do not, and cannot, know God'), because knowing God is a relational and responsive reality characterized by learning and growth where ever greater knowing is rightly accompanied by ever greater humility of unknowing.

Thirdly, within 34:6-7, the cumulative emphasis upon YHWH's mercy and forgiveness is remarkable. The epithets in v. 6 depict the attributes of the God whose name is YHWH, while the participial verbs of v. 7 depict the actions which express those attributes. The repetition of hesed ('steadfast love', vv. 6b, 7a) underlines the unwavering commitment of YHWH to His people. Comparison of v. 7 with the similar language in the second commandment (Ex. 20:5-6) shows not only the transposition of judgment from primary to secondary and less emphatic position, but also that the earlier stipulation, that the thousands who receive YHWH's steadfast love belong to the families of those who love and obey Him, is now absent and replaced by the affirmation of YHWH's comprehensive forgiveness. The fact that the warning attached to the second commandment can be reshaped thus, in the very context where Israel has failed to be obedient, is highly significant for the construal of such language, both in its biblical context and in its appropriate embodiment and use on the part of believers. To take it seriously should not mean to take it woodenly or without regard to the varying dynamics of the different contexts within which it appears (moral direction in Ex. 20, merciful restoration in Ex. 34); nor should it mean (as will be seen) playing the latter context off against the former, as though the seriousness of moral instruction and warning could be undercut by any facile appeal to divine mercy.

Fourthly, how should v. 7b ('but who will by no means clear the guilty, visiting the iniquity...') be understood? Prescinding from detailed exegetical issues, it is striking that the words are present here at all. YHWH has indeed brought judgment upon Israel (32:35), but 
there is surely a sense in which YHWH in ch. 34 is doing the very thing that He says He will not do, i.e. clearing the guilty. Why not solely specify mercy and forgiveness in this context? The likelihood is that, as Fretheim puts it, the words of v. $7 \mathrm{~b}$ constitute 'a continuing recognition of the moral order'; 54 that is, they serve to clarify that YHWH's forgiveness is truly forgiveness, not leniency, still less moral indifference. As such, they preserve a note of moral seriousness of the sort that should keep the mercy of YHWH from being misunderstood-either from the kind of mistaken complacency about God that is famously expressed in the words attributed to Heinrich Heine on his deathbed, 'Dieu me pardonnera, c'est son métier', or from the diminishing of the wonder of mercy in the kind of attitude famously characterized by Dietrich Bonhoeffer, at the outset of his Cost of Discipleship, as 'cheap grace'. This means that the unparalleled emphasis upon divine mercy and forgiveness is simultaneously accompanied by an implicit control to prevent the words from being misunderstood and misused.

Fifthly, the comparison of 34:6-7 with 20:5-6 reveals also that YHWH's jealousy ( $q n^{\prime}$ '), which one might expect to be mentioned, is absent from YHWH's self-proclamation in 34:6-7. However, it is not far away, for it is included in YHWH's continuing injunctions in the context of renewing the covenant (34:14); indeed, YHWH's jealousy here receives its strongest expression in the whole OT, so emphatic that His very name - which has just been emphatically associated with mercy, steadfast love, and forgiveness-is said to be Jealous (yhwh qannâs'šmo). YHWH's jealousy is like the jealousy of a husband for his wife, a refusal to allow Israel, His covenanted people, to dilute their faithfulness to Him by recognizing and tolerating other religious allegiances (34:11-16). It is a quality expressed in the first two commandments, the very ones which Israel has broken with the golden calf. We thereby have a clear tension within the text: the one whose nature is insistently merciful, even to Israel in its faithlessness, is the one whose nature it is to require exclusive faithfulness. Again, it seems clear that the text has been constructed in such a way as to prevent the kind of misunderstanding and abusing of divine mercy noted in the previous paragraph: divine mercy in no way means that 'anything goes', for the merciful one is also the demanding one. Unless these attributes of God are both respected with total

54 Terence E. Fretheim, Exodus (Interpretation Bible Commentary; Louisville: John Knox, 1991), 302. 
seriousness then the revelation of God will be more or less misunderstood. .5

\section{Conclusion}

Some may wonder why I have given such space to Preuss. After all, I do not imagine that a large number of the likely readers of this essay would be inclined to regard Preuss as a model in the first place. Yet Preuss is, I think, characteristic of an approach to OT/biblical theology which is shared by many who might disagree with the specifics of his analysis. First and foremost the task is to be depicted as a historical task, in which specifically theological/religious perspectives and beliefs on the part of the interpreter are to be bracketed as much as possible in order that the biblical text may be heard on its own terms. Secondly, however, such perspectives may be brought in at a secondary stage (depending on context and inclination) either to indicate some kind of assent to (or, in some cases, dissent from!) the message of the text, or make some kind of homiletic application. Thirdly, the question of how the meaning of the text might be responsibly recontextualized in contexts that are by definition other than its own (i.e. any Jewish or Christian theologizing) tends to be left hanging in the air. This whole way of setting up the nature of the task shows its origins in reaction to the dominant modes of theological interpretation in the 18th and 19th century development of biblical criticism.

I do not for a moment deny the need to learn to hear the voice of the biblical text, and that in this learning rigorous philological and historical disciplines play an invaluable role, and that certain beliefs may need to be bracketed at certain stages of the enterprise. But the very definition of the task as 'history' distinct from 'theology' may risk putting out of reach that which drives the task in the first place, i.e. the desire to hear not merely ancient and respected religious voices, but to encounter God and to hear God's voice in and through the medium of the biblical text. 56 So I would like to conclude with one proposal about the nature and practice of biblical theology as a scholarly discipline.

55 The tensions and paradoxes which are intrinsic to the OT portrayal recur in even sharper and deeper form in the NT portrayal of the death and resurrection of Jesus.

56 I have discussed this more fully in my The Bible, Theology, and Faith (CUP: 2000), ch.1. 
One emphasis in the above has been the question of the adequacy of the interpreter's categories of interpretation-what is necessary to be able to understand what the text is saying? The fact that biblical study has gained theoretical and institutional independence from dogmatic and systematic theology can all too easily mean that one may lapse into an implicit positivism where conceptual adequacy and ability to engage the subject matter of the text is not high on the agenda (which is one reason why Bultmann, despite his many deficiencies, continues to be worth studying). This means that wouldbe biblical theologians need to spend at least as much time studying and critically appropriating Christian (and Jewish) theology, ethics and spirituality in all their historic and contemporary richness (which necessarily engages with a range of other disciplines also) as in studying the latest monographs by their biblical and biblical Umwelt colleagues (which is one reason why Barth, despite his deficiencies, continues to be a vital resource for many). ${ }^{57}$ I say that such theology should be critically appropriated in order to prevent the idea that this wider range of study might be conducted in the same too narrowly construed mode of intellectual activity that so often characterizes biblical study. In other words, if biblical theology is to be true to itself, it needs to be a rigorous outworking of that openness and responsiveness towards God that we call prayer.

57 One way of reading my preliminary exposition abcve is as an attempt to show that recent proposals to regard doctrine as a grammar of Christian spcech ar. $\cdot$ well grounded in the biblical text: Ex. 34:6-7 is well construed as a prescriptic:1 for how YHWH may rightly be spoken of by Israel in its life and worship. 